JOURNAL OF TECHNOLOGY AND

OPERATIONS MANAGEMENT

http://e-journal.uum.edu.my/index.php/jtom

How to cite this article:

Nor, A. T. M., Nasir, F. M., \& Anuar, S. (2020). Eco-Friendly And Energy Efficient Vehicles. Journal of Technology and Operations Management, 15(2), 63-71. https://doi.org/10.32890/jtom2020.15.2.7

\title{
TECHNOLOGY PROGRESS IN AUTOMOTIVE SECTOR IN TERM OF ECO-FRIENDLY AND ENERGY EFFICIENT VEHICLES
}

\author{
${ }^{1}$ Ahmad Tarmizi Md Nor, ${ }^{2}$ Farhan Mat Nasir, \& ${ }^{3}$ Salwa Anuar \\ 1,2,3 Kolej Komuniti Kelana Jaya, Malaysia \\ Corresponding addresses: tarmizi@kkkj.edu.my
}

Received: 15/8/2020 Revised: 02/9/2020 Accepted: 30/11/2020 Published: 29/12/2020

\begin{abstract}
This paper mainly intended to highlight the importance of sustaining the technology of eco-friendly vehicles. This paper starts with a history of energy exploitation by a human being. The transition of energy source exploitation is running thru from the early renaissance time until this modern era of industrial revolution 4 (IR4.0). The internal combustion engine, in general, has served the world since early $20^{\text {th }}$-century driving until now. The depletion of oil reserves and the need to retain a green environment indicate the utmost important action must be taken to find an alternative source for new energy. This paper also highlights the concept technology cycle which in general, internal combustion engine technology has to reach the maturity stage, and innovation is needed to keep the engine technology up to date and create less pollution at the same time. Also, this paper reviews thefactors that will drive towards technology innovation and the progress of the eco-friendly vehicle.
\end{abstract}

Keywords: Electric Vehicle (EV), Energy Efficient Vehicle (EEV), Internal Combustion Engine (ICE)

\section{INTRODUCTION}

Human has always in need of power source to continue living. In early human has exploited natural resources like woods, coal for daily activities such as cooking and heat during winter. Heat generation employing burning woods and coal is not sustainable in the new era of industry mainly during the renaissance era in Europe back in the $14^{\text {th }}$ century. C. Wright (1996) said this sees the need for a new source of energy and human can no longer rely on woods and coal alone. As what being mentioned in the article entitled History of Oil (2018), by EKT Interactive, the invention of steam engines in the $18^{\text {th }}$ century capitalized the use of coal as its fuel thus lifted the industry of Europe and North America. During this era, coal was the main source of fuel in power generation. Industries have flourished in Europe and North America. The emerging of new machinery and technology requiresa massive amount of coal to fuel the industries at that time. This is parallel with R. Lukasz, (2018) research that 
stated burning of coals has put a tax on the environment thus in the dawn of the $20^{\text {th }}$ centuries, awareness of air pollution has become an issue thus open a window of exploration for a new source of energy that is the crude oil. For the past 100 years in the horizon of 21 st century, oil has been the key driver to the advancement of technology and its breakthrough has indeed catapultedthe world economy to a level human has not seen before, at least in the modern era. As in any case, everything has a reciprocal effect. According to A.T. Kearney (2017), as much as the exploitation ofoil has helped the advancement of industries all around the world, it has also contributed to the pollution of air caused by the burning of fossil fuel, at the upstream area the exploration has also caused damages to the environment.

\section{PROBLEM STATEMENT}

From day to day, car manufacturers always competing to create more energy-efficient vehicles that using less cost to get more distance and at the same time reduce the utmost pollution to the air. However, there is a lack of comparative study on technology progress in the automotive sector in terms of ecofriendly and energy-efficient vehicles. According to H. Ueno \& H. Mutoh, (1980), the automotive industry can be said as income-elastic whereas the automobile company stock was expected to increase faster than the increment of income level whereas it was 1.31in 8 leading countries. Meanwhile, it was rated 1.03 in other countries. Industrial productivity also increases as demand for automobile exports is also increased (H. Mutoh, 1988). Due to environmental and energy concerns, fuel consumption is the foremost design parameter. Transportation still depends on fossil fuels. In 2016, gasoline and diesel contributed $92 \%$ of the total energy used in transportation. The use of bioethanol and biodiesel is about $\% 5$. The contributions of natural gas and electricity are 3 percent and 1 percent, respectively. All over the world, $67 \%$ of global oil is consumed for transportation. A 70 percent increasein average oil demand which will contribute to a 130 percent rise in $\mathrm{CO} 2$ emissions is predicted by 2050 according to $\mathrm{D}$. Masson et al. (2018). This emission will increase global temperature estimated by $66^{\circ} \mathrm{C}$, which will result in irreversible climate change. Intergovernmental Panel on Climate Change (IPCC) offers that $\mathrm{CO} 2$ emissions should be reduced by $85 \%$ to hold the incremental global average temperature to below $2^{\circ} \mathrm{C}$ as written by D. Masson et al. (2018).

For sustainable transport and reduced $\mathrm{CO} 2$ emissions, the use of alternative fuels, electric and hybrid vehicles are promoted by P. Taylor (2010). Current research on full electrical vehicles and hybrid electrical vehicles aims to minimize the energy demand of vehicles and to optimize the energy control strategy. In these vehicles, the powertrain is replaced by electrical motors, power electronics, capacitors, and battery systems. The electrical equipment dynamically interacts with the mechanical parts of the vehicle. This interaction has to be optimized subject to general performance and energy consumption. However, sustainability in the automotive industry was not considered. In the present paper, simulation modeling is employed to incorporate a more general set of circumstances relating to green logistics particularly the consequence of carbon emissions in transportation, re-uses and recycling of materials, waste disposal, and optimal utilization of energy. A comprehensive review of the literature on green logistics is given by G. Ćirović et al. (2014). According to S. Jain et al., (2013), who developed system dynamics and discrete event model for a closed-loop supply chain system of a forklift brake, the author discovered some potential reductions at different nodes and used them to identify a target reduction of 29.4\% across the supply chain. According to S. Jain et al. (2013), the model represented a detailed operation of a plant with an offline set-up and estimated a 7\% reduction in energy consumption, thus will ensure pollution reduction.

Literature shows research on green technology has attracted significant academic attention in recent years as written by A. Roumboutsos et al. (2014). And many academicians have attempted to join pollution emissions and optimization models as part of their research. For example, I. Harris et al. (2014), the city logistic models proposed by frequently integrate emissions into a transportation model as shown in. However, the literature on this area reveals the absence of a modeling method that can combine some green objectives such as $\mathrm{CO} 2$ emissions, waste management, energy, and water conservation, hence this is the basis of this paper; to develop a simulation model combining these environmental externalities by M. Mousazadeh et al. (2014). 


\section{OBJECTIVE OF STUDY}

This article aims to study the scenarios in fossil fuel vehicles and compare the consumption of fuel with regards to the consumption of electrical energy and it will compare the emission of carbon dioxide (CO2) together with its significant effect on the environment. Thus, this will justify the importance of adopting a greener and environmentally friendly source of energy that is more sustainable in ensuring the longevity of our world at large.

\section{METHODOLOGY}

The methodology of the study was performed based on a paper reviewed on the history of technological progress of in automotive sector mainly in the development of energy-efficient vehicle and eco-friendly vehicles.

\section{Fossil Fuel Exploitation: The Scenario}

The European Union is steadfast to reduce average greenhouse gas emissions by 20 percent with regard 1990 baseline under Europe 2020 Strategy and the Kyoto Protocol's second period from 2013 to 2020 (C. Lodi et al, 2018). The biggest user of oil in the world would be the motor vehicles hence contributing to mass pollution of air that can be calculated by the $\mathrm{CO} 2$ emission as mentioned by research done by A. C. R. Teixeira and J. R. Sodré (2018), they found the energy consumed by electric-powered vehicle under NEDC test, was eight times lower than fuel energy vehicle. A. C. R. Teixeira, \&, J. R. Sodré (2018) found that technological evolution in the automotive industry also accelerated due to increasing of environmental concern mainly in reducing pollution and global warming emissions. Electric vehicle which is zero tailpipe emissions can be a key solution as internal combustion engine vehicles are main sources of pollutions and greenhouse gases with almost of global from overall $\mathrm{CO} 2$ emissions. To sustain a technology such as the eco-friendly technology this covers Electric Vehicle (EV), Solar Powered Vehicle (SPW) and Energy Efficient Vehicle (EEV) one must first understand the needs of such technology to exist. Currently, we consume about 4 billion tons of fossil fuels every year, going at this rate we only hope to have enough supply of fossilfuels up till the year 2052. Research by R. Boswell (2014), shows a positive gradient of oil price increase year by year is also the main reason for a human to start adopting and migrating from fossilfuels to cleaner green sources of energy.

According to Y. Chen et al (2013), the second factor that contributed to the need of sourcing new sources of power would be the impact of $\mathrm{CO} 2$ emission that put high taxes on the environment especially the air quality in all major cities. This situation sees dire needs for other sources of energy such as solar-powered vehicles and Electric powered Vehicles (EV) to be adopted in human daily life.

\section{DISCUSSION}

\section{Energy Consumption Effects on the Environment}

As mentioned earlier, fossil fuels have a great impact negatively on the environment especially on the quality of air around the world. To examine the effects of it, the angle of fuel consumption by vehicles and the emission of $\mathrm{CO} 2$ that contributed to the greenhouse effect have been carefully studied by A. C. R. Teixeira, \&, J. R. Sodré (2018). The author has compared the power consumption and the emission of $\mathrm{CO} 2$ between an internal combustion engine vehicle namely Vehicle A with an EV namely Vehicle B by using the AVL Cruise software. The simulations were done on the operation of both vehicles and table the result in Table 1 as shown below. 


\section{Table 1.}

CO2 emission and energy consumptions of Vehicle A and B (A. Rodrigues and J. Ricardo, 2018)

\begin{tabular}{lll}
\hline Parameter & Vehicle A & Vehicle B \\
\hline $\mathrm{CO}_{2}$ emissions $(\mathrm{g} / \mathrm{km})$ & 242.18 & - \\
Fuel energy consumption $(\mathrm{kWh} / \mathrm{km})$ & 0.8873 & - \\
Electric energy consumption $(\mathrm{kWh} / \mathrm{km})$ & - & 0.1084 \\
\hline
\end{tabular}

This introduction of electric vehicles in the taxi group at the city of Sete Lagoas, MG, Brazil as a case study to analyze energy consumption and $\mathrm{CO} 2$ emissions. This research is braced by a simulation of two identical vehicles driven by an electric motor and internal combustion engine by using the AVL Cruise software. The consumption of the energy of both vehicles traveling the same distance and about the same speed are also presented in the author's paper. The results are depicted in Fig. 1 and Fig. 2.

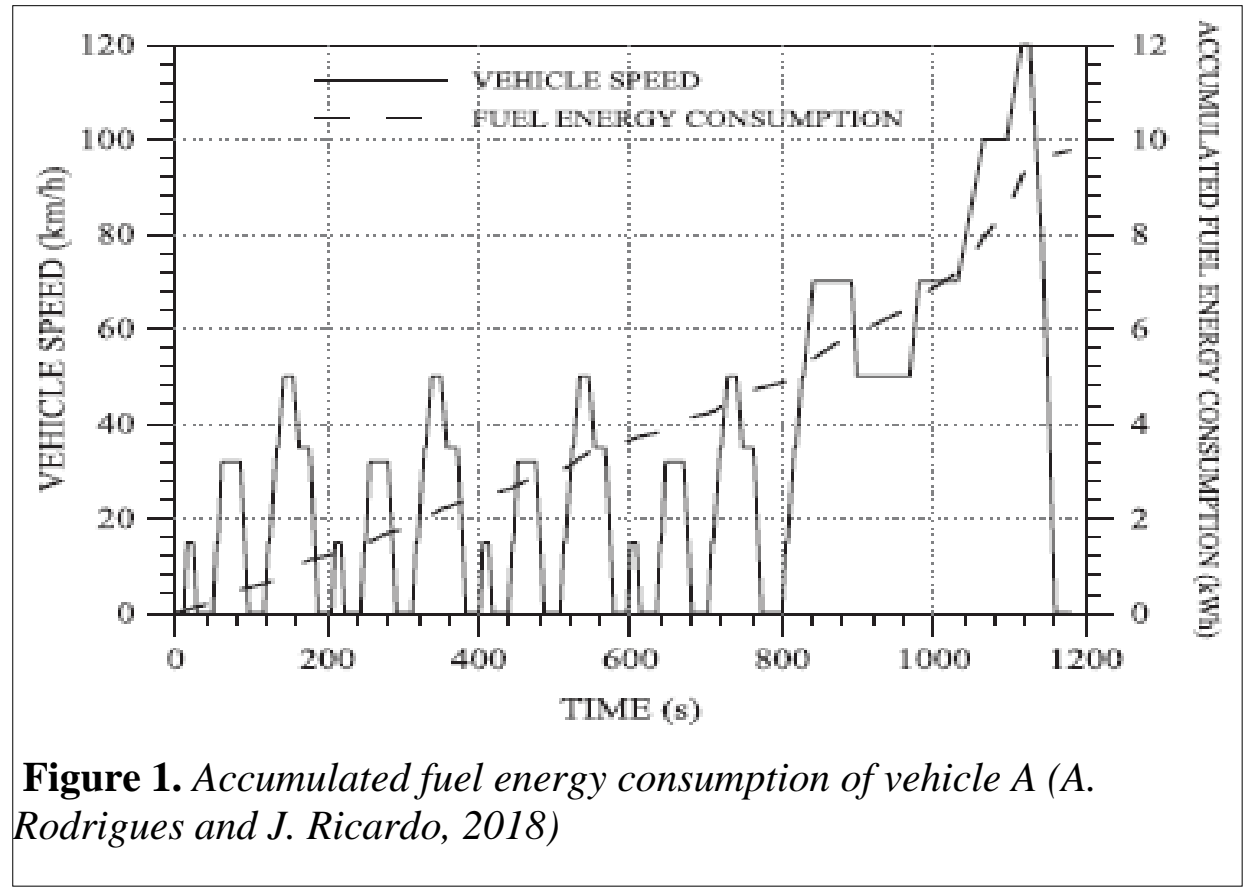




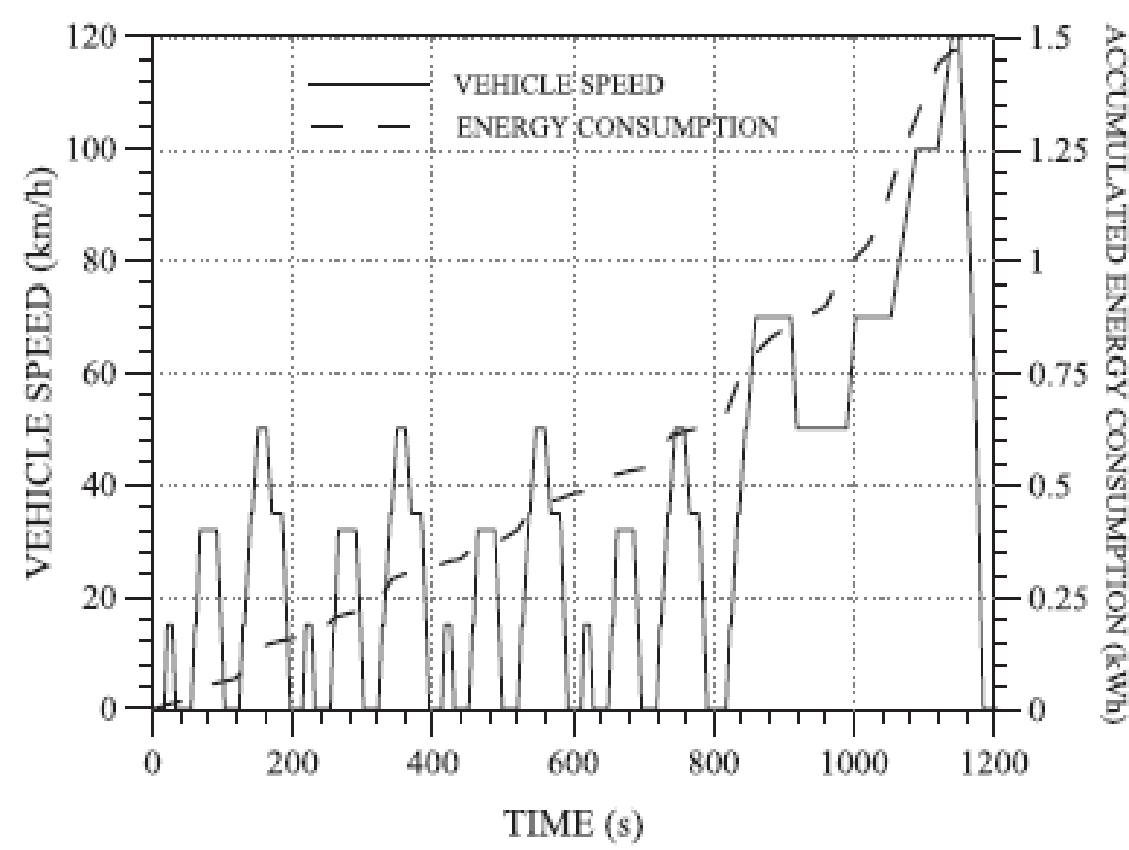

Figure 2. Accumulated electrical energy consumption of vehicle $B$ (A. Rodrigues and J. Ricardo, 2018

The unit used to measure the consumption of energy is kilowatts per hour per kilometer distance $(\mathrm{kW}$ $\mathrm{h} / \mathrm{km}$ ). As we can see in Fig. 1 and Fig. 2, both vehicles traveling at the same range of time with almost identical speed show significant differences in energy consumption. As for vehicle $A$, the consumption was $0.8873 \mathrm{~kW} \mathrm{~h} / \mathrm{km}$ and for Vehicle B the energy consumption was $0.1084 \mathrm{~kW} \mathrm{~h} / \mathrm{km}$. These results or energy consumption by both vehicles indicates a positive and promising situation for $\mathrm{EV}$ to replace the conventional internal combustion engine. $\mathrm{CO} 2$ emission is measured with unit $\mathrm{g} / \mathrm{km}$. The issue of air pollution contributed by the emission of $\mathrm{CO} 2$ once again indicated in the result of the simulation done which indicates positive news for the environment by showing $0 \mathrm{~g} / \mathrm{km}$ emission of $\mathrm{CO} 2$ by vehicle A(electrical vehicle) compared to $242.18 \mathrm{~g} / \mathrm{km} \mathrm{CO} 2$ emission by vehicle $\mathrm{B}$ (internal combustion engine).

\section{Going Forward with Electrical-Powered Vehicle}

Base on C. McGlade and P. Ekins, (2015), in this $21^{\text {st }}$ century the main concerns are environmental protection and energy conservation which accelerated the progress of electric vehicle technology. Zero tailpipe emissions with the capability of a smart transportation system for sure giving electric vehicles more advantage in terms of efficiency. This matter is supported by M. S. Kumara and S. T. Revankar (2017) which said to be commercially feasible with consistent operation at affordable cost is the main objective of investing for the development of electric vehicle compare to it direct rival which is internal combustion engine vehicle. According to M. S. Kumara and S. T. Revankar (2017) also, 1918 was the mark of the earliest availability of the Earliest Electric Vehicles (EVs). The rapid development of the internal combustion engine was the main cause of the slow development of electric vehicle technology at that period. This has resulted in limited utilization of EV as an option for road transportation in those days. Nonetheless, due to the recent sensitivity of the world population with regards to the environmental effects that fossil fuels have caused, there is a steep gradient of interest from many quarters to develop EV as the alternative to ICE. Furthermore, looking at the current oil reserve that which shows that we are going to face a supply crisis by the year 2052, it would be a smart move to hugely spend on development and reorganize EV as the main mode of transportation towards the future. (B. Nykvist, and N. Måns, 2015). 
Looking beyond the era of exploiting the fossil fuel, we must look and consider alternative energy sources which are in abundant. Options available such as solar energy, wind energy, and harvesting of energy created by ocean waves should be the way forward. In recent times, the energy carrier that sees fits would be the electrical energy. Since transportation takes up to $20 \%$ of the whole portion of fossil fuel consumption, according to G. Zivin et al (2014), the need to migrate transportation dependency from fossil fuel to electrical energy would be the most practical and efficient steps to take. Thou electrical energy being the carrier seems promising nonetheless it has few challenges that need to be addressedtechnologically such as the issue of battery for energy storage and the generation of electricity. J. Herman (2017) stated that although the electric vehicle is zero tailpipe emission but the electricity generation which for car charger would also contribute to the net emission. $\mathrm{CO} 2$ emissions will be larger than those produced by gasoline vehicle if an electricity power plant source is powered by coal as coal produces more $\mathrm{CO} 2$ than gasoline or diesel for the same amount of energy due to net efficiency about 35 percent compared to gasoline which about 20 to 25 percent of net efficiency. Thus, replacing the internal combustion engines with an electrical vehicle is not a direct solution to the greenhouse gases if the electric generation efficiency is not taken into serious consideration. To ensure the sustainability of technology in eco-friendly vehicles, several key elements must be put into consideration. The basic aspect of any technology to be successful and sustainable linger around three main basic contributors namely competing for political, moral, and economic demands as mentioned by A. Lenferna (2017). From the perspective of technology advancement, the storage of electrical energy needs high-efficiency batteries. Currently, the Li-ion batteries come with an energy density of around $0.25 \mathrm{kWh} / \mathrm{kg}$ meanwhile electric cars on average per hour of driving consumed about $15 \mathrm{kWh}$. A. Lenferna (2017) also highlighted that an hour of driving will require a $6 \mathrm{~kg}$ battery to feed the electrical motor of the vehicle. Furthermore, with relation to the electrical motor, charging and discharging circuitry must also be improved to cater to the technology required for an efficient operation of the EV charging time done domestically.

\section{CONCLUSION}

To sustain the technology in ensuring the sustainability of the existent of the human race, many factors need to be considered and affirmative action should be taken. Internal Combustion Engine has arrived at its maturity stage where the depletion of fossil fuel has pushed the industries to source for an alternative energy source which in this case it is electrical energy. A leap from the current situation can be understood by looking at the concept of the S-Curve.

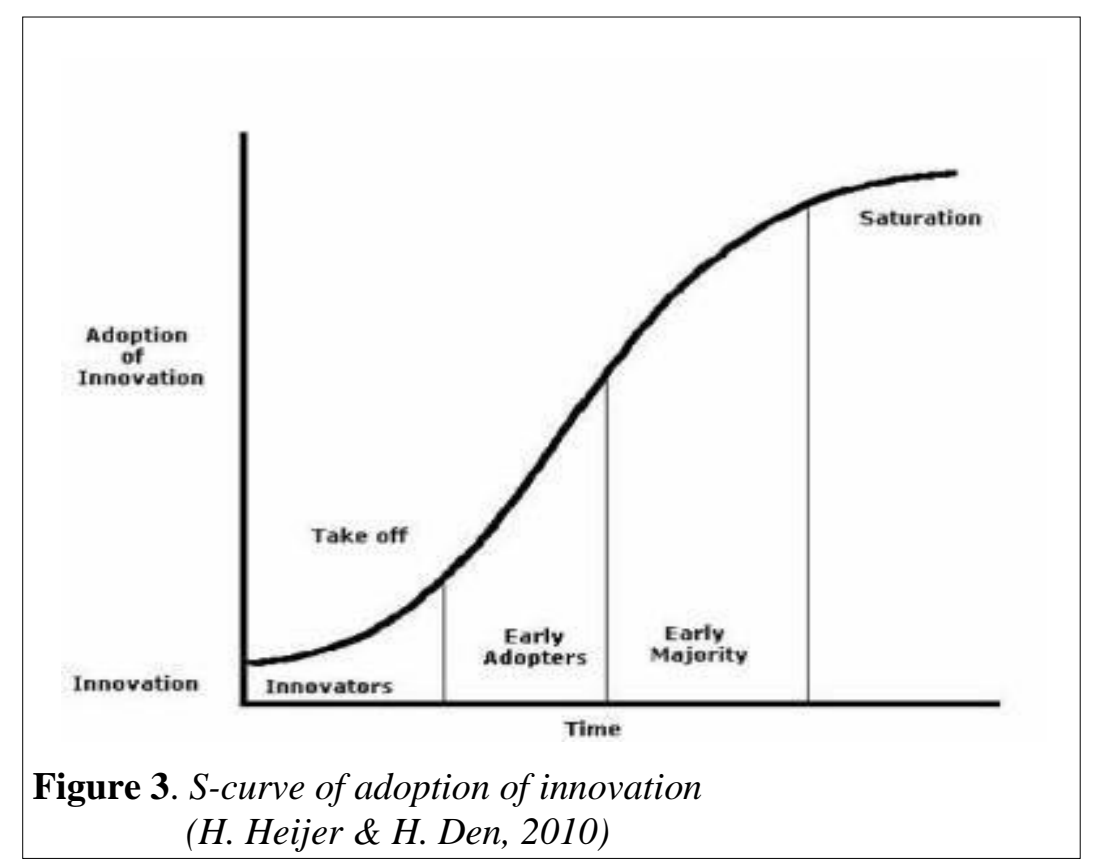


H. Heijer and H. Den (2010), described innovation with the term production function which is used to identify the processed within a specific company on their technology level. The building blocks of this function compromise of few factors such as raw materials, labor; semi-manufactured products, and added services, which leads to a certain outcome at the production stage.

As the quantity of the production factor changes, the level of output will also show significant changes. Yet it is still not referred to as an innovation. Innovation is only done as the form of the function itself changes. H. Heijer and H. Den (2010) also mentioned that new technology that will turn out to be the industry standard can emerge from many directions such as from high performing or below par. Also they may emerge from incumbents as well as those newcomers either at a fast or slow pace (K. Hatten et al, 1976).

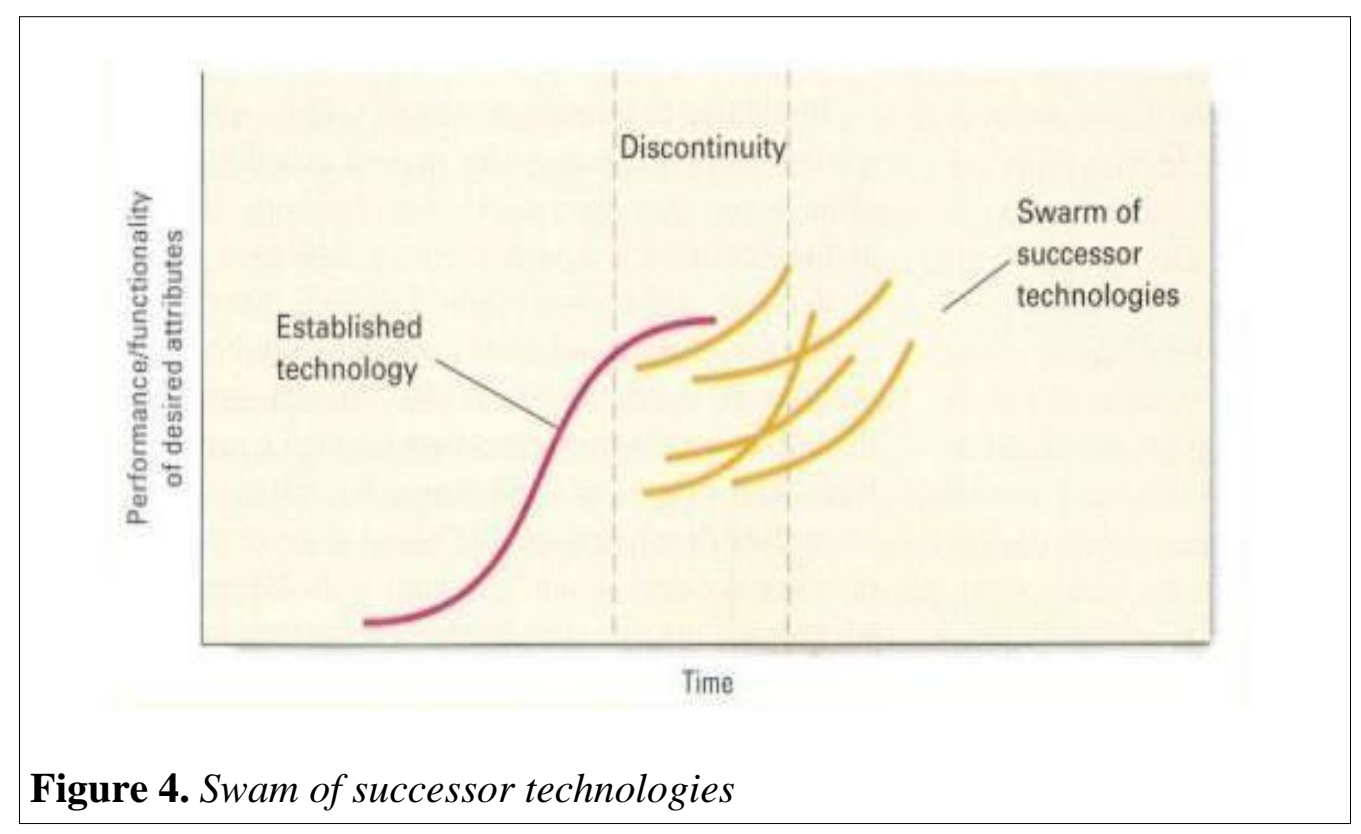

Internal Combustion Engine has arrived at its maturity stage where the depletion of fossil fuel has pushed the industries to source for an alternative energy source which in this case it is electrical energy. A leap from the current situation can be understood by looking at the concept of the SCurve and the concept of "swam of a successor" as depicted in Fig. 3 and Fig. 4.

\section{Table 2.}

Parties and stake-holders functions ensuring the sustainability of the EV technology

\begin{tabular}{lll}
\hline & Stakeholders & Action \\
\hline Political will/drive & United Nations, NATO, EU, & $\begin{array}{l}\text { Declarations and } \\
\text { initiative }\end{array}$ \\
& ASEAN, Governments. etc. & $\begin{array}{l}\text { with affirmative actions } \\
\text { Invest more in research } \\
\text { and } \\
\text { Economically/Investors/ }\end{array}$ \\
Technology player & Tesla, Samsung, Toyota .etc & \\
& & design erts. \\
\hline
\end{tabular}




\begin{tabular}{lll}
\hline Universities/Technical Lab & Universities and research entities & $\begin{array}{l}\text { Collaborate with } \\
\text { funders and end-users } \\
\text { to come out with } \\
\text { better designs and } \\
\text { applicable } \\
\text { products. }\end{array}$ \\
& $\begin{array}{l}\text { Educate the young } \\
\text { generation on the } \\
\text { importance of green }\end{array}$ \\
People & $\begin{array}{l}\text { United Nations Educational, } \\
\text { Scientific and Cultural } \\
\text { Organization (UNESCO) } \\
\text { respective governmental } \\
\text { agencies related to education. }\end{array}$ & $\begin{array}{l}\text { concept of } \\
\text { sustainability. }\end{array}$ \\
& &
\end{tabular}

Hence many parties and stakeholders must work hand-in-hand in ensuring the sustainability of the EV technology which eventually sustains and prolong the existent of the human race as long as possible.

\section{ACKNOWLEDGEMENT}

This research received no specific grant from any funding agency in the public, commercial, or not-forprofit sectors.

\section{REFERENCES}

A. C. R. Teixeira, \&, J. R. Sodré (2018). Impacts of replacement of engine-powered vehicles by electric vehicles on energy consumption and CO 2 emissions. Transportation Research Part D: Transport and Environment, 59, 375-384.

A. Lenferna (2017). Fossil Fuel Divestment Report for the Seattle City Employees Retirement System.

A.T. Kearney (2017), Technology and Innovation for the Future of Production: Accelerating Value Creation, World Economic Forum 91-93 route de la Capite CH-1223 Cologny/Geneva Switzerland.

A Roumboutsos, S. Kapros, and T. Vanelslander (2014). "Green city logistics: Systems of Innovation to assess the potential of E-vehicles," Res. Transp. Bus. Manag., vol. 11, pp. 43-52, Jul.

B. Nykvist, and N. Måns (2015). "Rapidly falling costs of battery packs for electric vehicles." Nature Climate Change 5, 329-332.

C. Lodi, Seitsonen, A., Paffumi, E., De Gennaro, M., Huld, T., \& Malfettani, S. (2018). Reducing CO 2 emissions of conventional fuel cars by vehicle photovoltaic roofs. Transportation Research Part D: Transport and Environment, 59, 313-324.

C. Wright (1996). Challenges for the E\&P industry in the 21st Century, Petroleum Geology Conference '96, December 9-10, 1996, Kuala Lumpur.

C. McGlade, and P. Ekins, (2015). "The geographical distribution of fossil fuels unused when limiting global warming to $2{ }^{\circ} \mathrm{C}$." Nature 517 (January 8).

D. Masson, V., P. Zhai, H.-O. Pörtner, D. Roberts, J. Skea, P.R. Shukla, A. Pirani, W. MoufoumaOkia, C. Péan, R. Pidcock, S. Connors, J.B.R. Matthews, Y. Chen, X. Zhou, M.I. Gomis, E. Lonnoy, T. Maycock, M. Tignor, and T. Waterfield, (2018) IPCC: Summary for Policymakers. In: Global Warming of $1.5^{\circ} \mathrm{C}$. An IPCC Special Report on the impacts of global warming of $1.5^{\circ} \mathrm{C}$ above pre-industrial levels and related global greenhouse gas emission pathways, in the context of strengthening the global response to the threat of climate change, sustainable development, and efforts to eradicate poverty [ (eds.)]. World Meteorological Organization, Geneva, Switzerland, 32 pp. 
G. Ćirović, D. Pamučar, and D. Božanić (2014). "Green logistic vehicle routing problem: Routing light delivery vehicles in urban areas using a neuro-fuzzy model," Expert Syst. Appl., vol. 41, no. 9, pp. 4245-4258, Jul.

G. Zivin, Joshua, M. Kotchen, and E. Mansur (2014). "Spatial and temporal heterogeneity of marginal emissions: Implications for electric cars and other electricity shifting policies." Journal of Economic Behavior and Organization, 107: 248-268.

H. Heijer \& H. Den (2010). Managerial Usefulness of S-curve Theory: Filling the Blanks, 31.

H. Ueno and H. Mutoh, (1980). The Automotive Industry of Japan, In Kazuo Sato, (ed), Industry and Business in Japan, M.E Sharpe, Inc., New York, pp. 139-190.

I. Harris, C. L. Mumford, and M. M. Naim (2014). "A hybrid multi-objective approach to capacitated facility location with flexible store allocation for green logistics modeling," Transp. Res. Part E Logist. Transp. Rev., vol. 66, pp. 1-22, Jun.

J. Herman (2017). The challenge of energy-efficient transportation. MRS Energy Sustain, 4(1).

K. Hatten, D. Schendel and A. Cooper(1976). A Strategic Model of the U.S. Brewing Industry: 1952-

1971 The Academy of Management Journal Vol. 21, No. 4 (Dec. 1978), pp. 592-610

R. Lukasz (2018). History of Oil - A Timeline of the Modern Oil Industry. Retrieved from https://ektinteractive.com/history-of-oil/

R. Boswell, (2014). "Methane Hydrates." Future Energy (Second Edition).

M. Mousazadeh, S. Torabi, and M. Pishvaee (2014). "Green and Reverse Logistics Management Under Fuzziness," Supply Chain Management.

M. S. Kumar and S. T. Revankar (2017). "Development scheme and key technology of an electric vehicle: An overview,” Renew'. Sustain. Energy Rev., vol. 70, no. July 2016, pp. 126A1285.

H. Mutoh(1988). The Automotive Industry, In Ryutaro Komiya et al. (eds), Industrial Policy of Japan, Academic Press Inc., California.

P. Taylor (2010). "Energy Technology Perspectives 2010-Scenarios and Strategies to 2050," International Energy Agency, Paris 74

S. Jain, E. Lindskog, J. Andersson, and B. Johansson (2013). "A hierarchical approach for evaluating energy trade-offs in supply chains," Int. J. Prod. Econ., vol. 146, no. 2, pp. 411-422, Dec.

Y. Chen, E. Avraha, G. Michael, and L. Hongbin (2013). "Evidence on the impact of sustained exposure to air pollution on life expectancy from China's Huai River policy." Proceedings of the National Academy of Sciences, 110(32): 12936-12941. 